\title{
Exclusive jurisdiction clauses in international trust deeds - ERRATUM
}

\author{
Ardavan Arzandeh
}

https://doi.org/10.1017/lst.2021.7, Published by Cambridge University Press, 05 April 2021.

Several corrections were missed during the amendment process for this article. The corrections have been listed out below. The publishers would like to apologies for this oversight.

Page 2, Paragraph 2:

"except when the claimant can show..." should instead read "unless the claimant can show..."

Page 2, Paragraph 3:

"The main body of the paper contains three parts" should instead read "The main body of the paper contains three sections"

Page 3, Paragraph 3:

"Similarly, and without prejudice to Brussels Ia Regulation, ${ }^{13}$ Articles 24 or 26, English courts are obliged to decline jurisdiction where an EU Member State has competence pursuant to Brussels Ia Regulation, Article 25"

should instead read:

"Similarly, while Brussels Ia Regulation, ${ }^{13}$ was in operation in England, without prejudice to Articles 24 and 26 of that instrument, English courts were obliged to decline jurisdiction where an EU Member State had competence by virtue of Article $25^{14 \text { ” }}$

Page 3, Footnote 14:

The current Footnote 14 should be disregarded. The correct Footnote should instead appear at the end of the previous sentence and read as follows:

"In relation to proceedings that were initiated in England before the end of the Brexit transition period - namely, 31 December 2020 - the jurisdiction rules under the Brussels Ia Regulation will continue to apply."

Page 4, Footnote 21:

This footnote should have been amended to read as follows: 
"With regard to proceedings that have been initiated before the courts in England prior to the end of the Brexit transition period, anti-suit injunctions to restrain litigations from commencing (or continuing) proceedings in an EU Member State remain unavailable, even if the action is brought in bad faith (Case C-159/02 Turner v Grovit [2004] ECR I-3565; [2005] 1 AC 101), or in breach of an arbitration agreement (Case C-185/07 Allianz SpA (formerly Riunione Adriatica di Sicurtà SpA, Generali Assicuranzioni Generali SpA) v West Tankers Incorporation [2009] ECR I-663; [2009] 1 AC 1138).”

Page 14, Footnote 95:

This footnote should have read as follows:

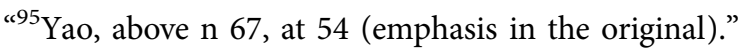

\section{Reference}

Arzandeh, A. (2021). Exclusive jurisdiction clauses in international trust deeds. Legal Studies, 1-18. doi:10.1017/lst.2021.7

Cite this article: Arzandeh A (2021). Exclusive jurisdiction clauses in international trust deeds - ERRATUM. Legal Studies 41, 545-546. https://doi.org/10.1017/lst.2021.44 